University of Nebraska - Lincoln

DigitalCommons@University of Nebraska - Lincoln

Biological Systems Engineering: Papers and

Publications

Biological Systems Engineering

2014

\title{
Use Of Controller Area Network (Can) Data To Determine Field Efficiencies Of Agricultural Machinery
}

\author{
Santosh Pitla \\ University of Nebraska-Lincoln, spitla2@unl.edu \\ N. Lin \\ University of Nebraska-Lincoln \\ Joe D. Luck \\ University of Nebraska-Lincoln, jluck2@unl.edu \\ Scott A. Shearer \\ University of Nebraska-Lincoln
}

Follow this and additional works at: https://digitalcommons.unl.edu/biosysengfacpub

Part of the Bioresource and Agricultural Engineering Commons, Environmental Engineering Commons, and the Other Civil and Environmental Engineering Commons

Pitla, Santosh; Lin, N.; Luck, Joe D.; and Shearer, Scott A., "Use Of Controller Area Network (Can) Data To Determine Field Efficiencies Of Agricultural Machinery" (2014). Biological Systems Engineering: Papers and Publications. 463.

https://digitalcommons.unl.edu/biosysengfacpub/463

This Article is brought to you for free and open access by the Biological Systems Engineering at DigitalCommons@University of Nebraska - Lincoln. It has been accepted for inclusion in Biological Systems Engineering: Papers and Publications by an authorized administrator of DigitalCommons@University of Nebraska Lincoln. 


\title{
Use of CONTROLlER AREA NetWork (CAN) DATA TO DETERMINE FIELD EFFICIENCIES OF AGRICULTURAL MACHINERY
}

\author{
S. K. Pitla， N. Lin，S. A. Shearer，J. D. Luck
}

\begin{abstract}
Controller Area Network (CAN) bus is used on current agricultural equipment for in-vehicle communication among multiple microcontrollers. In this study, CAN data was collected from the tractor diagnostic port during three field operations: anhydrous ammonia $\left(\mathrm{NH}_{3}\right)$ application, field cultivation, and planting. Specifically, CAN messages corresponding to engine fuel use rate were filtered, decoded, and analyzed. High fuel use rates were recorded from the tractor when implements were engaged in the soil compared to when the implements were lifted out of the ground at the end of the passes or, when the tractor was turning and idling. Threshold fuel rates (TFR) in liter per hour per tool for each operation were established based on the draft force requirements of the implements to distinguish between working and dwell periods. Using the calculated TFRs of 2.58 to $2.64 \mathrm{Lh}^{-1}$ tool ${ }^{-1}, 0.41$ to $0.50 \mathrm{Lh}^{-1}$ tool $l^{-1}$ and 1.46 to $1.65 \mathrm{Lh}^{-1} \mathrm{row}^{-9}$, average field efficiencies (FE) of anhydrous $\mathrm{NH}_{3}$ application, field cultivation and planting were determined to be $71 \%$, $71 \%$ and $68 \%$, respectively. It was found that $F E$ values for the planting operation were highly sensitive to variation in TFR when contrasted with anhydrous $\mathrm{NH}_{3}$ application and field cultivation operations.
\end{abstract}

Keywords. Automation, Communication, Controller, Draft power, Field efficiency, Implements.

$\mathrm{A}$ gricultural machine field efficiencies (FE) have a significant effect on the field capacities (area covered in a given time) which in turn impact the overall cost of production. FE is defined as the ratio of productivity of a machine under field conditions to the theoretical maximum productivity (ASAE 2006). Major factors that affect machine $\mathrm{FE}$ are the time required for turning, idle time, refill time (seeds, fertilizers and chemicals), machine width and field shape. Another definition of FE is the ratio of effective to theoretical field capacity expressed in percent where effective field capacity is the actual rate of land or crop processed in a given time and theoretical field capacity refers to the performance of a machine functioning $100 \%$ of the time at a given operating speed using $100 \%$ of its theoretical width (ASAE 1999). Initially, time motion studies were performed to estimate implement FE, but with the advent of precision agricultural technologies, Global Positioning System (GPS) data has been used to determine FEs (Taylor et al., 2001, Taylor et al., 2002, Grisso et al., 2002 and Grisso et al., 2004). A study by Taylor et al (2001) reported that FE of planters reduced with increasing width and was not affected

Submitted for review in February 2014 as manuscript number PM 10618; approved for publication by the Power \& Machinery Division of ASABE in August 2014.

The authors are Santosh K. Pitla, ASABE Member, Assistant Professor, Department of Biological Systems Engineering, Nannan Lin, ASABE Member, Graduate Student, Department of Food Agricultural and Biological Engineering, Scott A. Shearer, ASABE Fellow, Professor and Chair, Department of Food Agricultural and Biological Engineering, and Joe D. Luck, ASABE Member, Assistant Professor, Department of Biological Systems Engineering, University of Nebraska-Lincoln. Corresponding author: Santosh K. Pitla, 207 L.W. Chase Hall, Lincoln, NE; phone: 859-351-0485; e-mail: spitla2@unl.edu. by the size of the field. In fields with straight rows versus fields with contour patterns, FEs of planters and harvesters were reduced by $10 \%$ and $20 \%$, respectively (Grisso et al., 2002). Some researchers integrated GPS and machine specific communication data to evaluate the productivity of machines.

Automated data acquisition from machinery was performed using standardized electronic communication such as Landwirtschaftliches BUS-System (LBS) and GPS for agricultural production traceability (Demmel et al., 2002 and Auernhammer et al., 2000). As part of this work, an Implement Indicator (IMI) was developed which could identify and run data acquisition programs on implements that did not have their own electronics. This automated geo-referenced machine data acquisition improved farm management and decision making. Modern field machinery is equipped with International Standard Organization (ISO) bus which operates on ISO 11783 communication protocol. This protocol is an expanded version of Society of Automotive Engineers (SAE) J1939 CAN bus vehicle network communication standard that was specifically developed for agricultural and forestry equipment (Stone et al., 1999). This manuscript demonstrates the ability to determine the FEs of agricultural operations using CAN bus data obtained from the tractors.

\section{OBJECTIVES}

The objectives of this study were to

1. Determine Threshold Fuel Rates (TFRs) for anhydrous application, field cultivation and planting operations and evaluate the FE sensitivity to variation in draft loads and the TFRs. 
2. Determine FE of crop production operations (e.g., anhydrous application, field cultivation and planting) from the tractor generated fuel use rate CAN message data and the TFRs.

\section{MATERIALS AND MeTHODS}

For this study, CAN bus data were collected from the ISO diagnostic port of a four wheel drive (4WD) tractor (JD 9410R, Deere \& Co., Moline, Ill.) and a mechanical front wheel drive (MFWD) tractor (JD 7215R, Deere \& Co., Moline, Ill.). The 4WD tractor was used to pull a $10 \mathrm{~m}$ wide anhydrous $\mathrm{NH}_{3}$ applicator (DW 6032, Dalton Ag Products, Lenox, Iowa) and a $13.7 \mathrm{~m}$ wide field cultivator (JD 2210, Deere \& Co., Moline, Ill.) whereas, the MFWD tractor was used to pull a 16 row corn planter that was $12.2 \mathrm{~m}$ wide (see fig. 1 ).

A total of six distinct fields were considered for this study (see table 1). For field cultivation (secondary tillage) and planting operations, CAN data were collected in three fields whereas data from only two fields were obtained for anhydrous application due to bad weather and logistics issues. The field operations took place during the months of

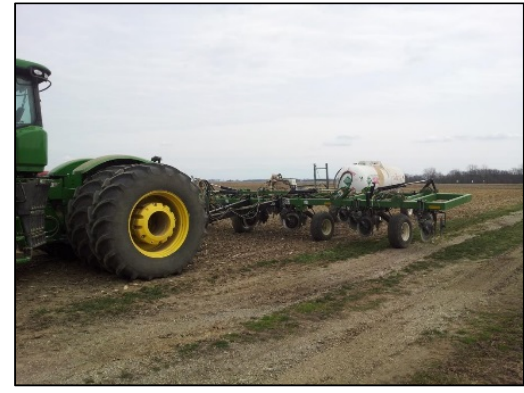

(a) Anhydrous $\mathrm{NH}_{3}$ Applicator

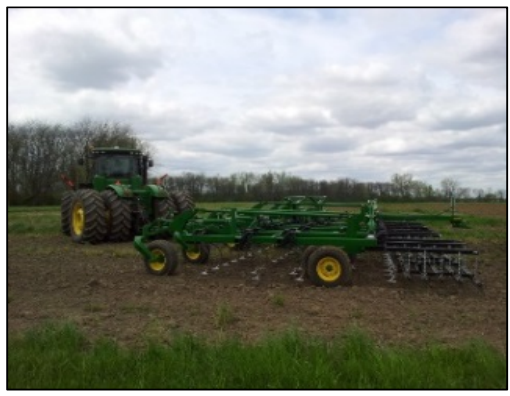

(b) Field Cultivator
April and May, 2013 at the Farm Science Review farm located near London, Ohio.

A CAN bus analyzer (CANcase XL log, Vector, Stuttgart, Germany) was used to obtain CAN messages from the tractor diagnostic ports (fig. 2). The CAN hardware was interfaced with the laptop through a Universal Serial Bus (USB) port and the data were stored in an American Standard Code for Information Interchange (ASCII) file in real-time during field operations

Two channels on the CANcase XL log box were configured to receive messages from both the tractor and implement bus channels of the ISO diagnostic port. The baud rate on channel 1 was set to $500 \mathrm{~kb} / \mathrm{s}$ whereas channel 2 was set to $250 \mathrm{~kb} / \mathrm{s}$ to match the tractor and implement bus baud rate settings, respectively. All messages available on the tractor and implement bus were recorded for post processing. A screenshot of the CAN messages recorded from the tractor CAN bus can be seen in figure 3 . The message highlighted in figure 3 corresponded to the tractor fuel consumption identified as the Liquid Fuel Economy (LFE) message. The fuel economy message was selected for analysis as it was not a proprietary message and could be used for multiple purposes including the calculation of fuel consumed for a particular operation and

Figure 1. (a) Anhydrous $\mathrm{NH}_{3}$ applicator (b) Field cultivator and (c) 16 Row corn planter.

Table 1. Summary of operations, fields and equipment used for the study.

\begin{tabular}{|c|c|c|c|c|c|c|c|}
\hline Operation & $\begin{array}{c}\text { Tractor } \\
\text { Used }\end{array}$ & $\begin{array}{c}\text { Tractor } \text { PTO }_{\text {rated }} \\
(\mathrm{kW})\end{array}$ & Implement & $\begin{array}{l}\text { Width } \\
(\mathrm{m})\end{array}$ & $\begin{array}{c}\text { Number of } \\
\text { Fields }\end{array}$ & $\begin{array}{c}\text { Field } \\
\text { Names }\end{array}$ & $\begin{array}{c}\text { Field Area } \\
\text { (ha) }\end{array}$ \\
\hline Anhydrous $\mathrm{NH}_{3}$ application & 4WD & 245 & $\mathrm{NH}_{3}$ applicator & 13.7 & 2 & 4A, 3MSID & 11,12 \\
\hline $\begin{array}{l}\text { Field cultivation } \\
\text { (secondary tillage) }\end{array}$ & 4WD & 245 & Field cultivator & 10 & 3 & $1 \mathrm{C}, 2 \mathrm{C}, 2 \mathrm{D}$ & $10,10,11$ \\
\hline Planting & MFWD & 142 & Corn planter (central fill) & 12.2 & 3 & $1 \mathrm{C}, 2 \mathrm{D}, 12 \mathrm{D}$ & $10,11,18$ \\
\hline
\end{tabular}

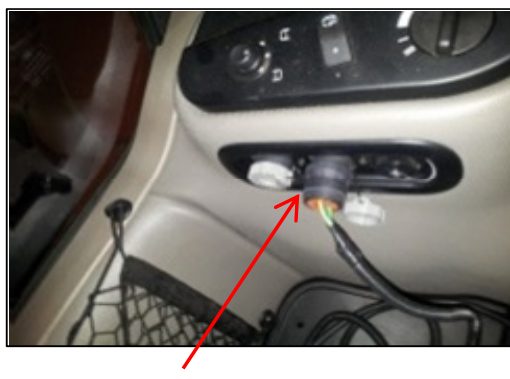

(a) ISO Diagnostic Port on the tractor

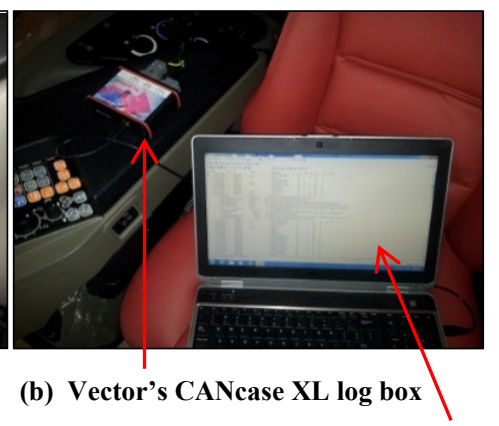

CANalyzer ${ }^{\mathrm{TM}}$ Interface on the laptop

Figure 2. CAN hardware setup inside the tractor cab (a) ISO diagnostic port, (b) CANcase XL log box, and CANalyzer Interface. 


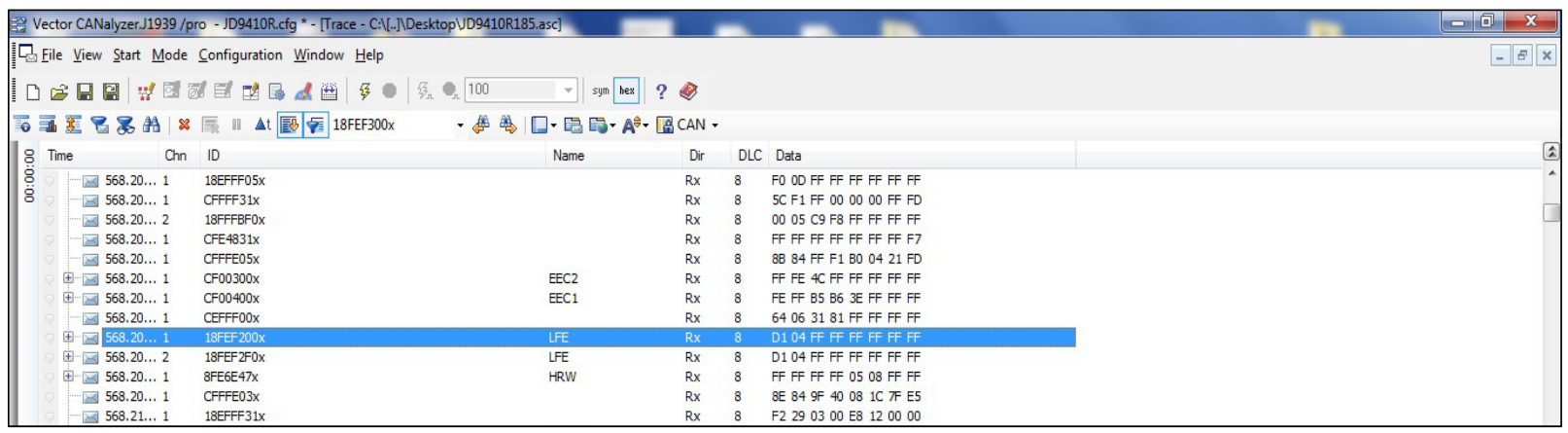

Figure 3. Screenshot of the CAN messages recorded from JD 9410R tractor during anhydrous $\mathrm{NH}_{3}$ application.

the estimation of engine load. The message identifier (Msg ID) in hex format of this message was 18FEF200x (see fig. 3) based on the SAE standard database document (SAE, 2013). The ASCII file record contained both proprietary and SAE-registered CAN bus messages and was filtered to obtain LFE messages which contained fuel use rate data in hexadecimal format.

The bytes of data in the message were decoded using the format and resolution information available in the SAE J1939 database (SAE, 2013). The LFE message updated at a rate of $10 \mathrm{~Hz}$ and provided engine fuel use rate in $\mathrm{Lh}^{-1}$ with a resolution of $0.05 \mathrm{Lh}^{-1} \mathrm{bit}^{-1}$. The converted fuel use rate was then plotted versus time to observe the fuel use rate variation during field operations. In addition to CAN messages, data files from Trimble's FMX display (Trimble Navigation, Ltd., Sunnyvale, Calif.) were downloaded which provided the National Marine Electronics Association (NMEA) GPS data (speed, latitude and longitude) of the tractors during field operations. The tractors were equipped with Trimble's Autopilot ${ }^{\mathrm{TM}}$ (Trimble Navigation, Ltd., Sunnyvale, Calif.) for automated guidance. CAN messages corresponding to vehicle navigation were not recorded as those messages were not available either on the tractor or implement bus of the diagnostic ports. So, the tractor path data analysis was done using GPS data with Real Time Kinetic (RTK) correction obtained from the FMX monitors. Thus, the CAN message corresponding to fuel use rate of engine with Msg ID: 18FEF200x and the NMEA GPS data obtained from the Trimble's FMX display were used in the determination of the FE.

To determine the FE of operations from the fuel use rate data, it was important to identify the duration or period when the tractor-implement combination was actually performing the intended operation from the time series fuel use rate plot. It is implicit that whenever the implement is engaged in the soil the fuel use rate of the tractor is higher due to increased engine load. Thus, the periods of high fuel use rates were treated as working period (WP) where the implement is engaged in the soil and the periods of low fuel use rates were referred to as dwell period (DP) during which the implement was out of the ground. However, to distinguish between WP and DP, appropriate values for fuel use rate during each period must be established. The Threshold Fuel Rate (TFR) value for each implement was used to separate WP from DP in the fuel use rate profile.
WP would be the time duration during which the tractor fuel use rate is greater than or equal to the TFR and DP corresponds to the remaining time periods. Equation 1 can be used to determine the FE of the operation using WP and DP.

$$
F E(\text { decimal })=\frac{W P}{(W P+D P)}
$$

where

$W P=$ working period (s), it is the time period during which the implement is working or when implement is engaged in the soil

$D P=$ dwell period (s), it is the time period (s) during which the implement is not doing useful work

The denominator in equation 1 is the total duration of time (s) the tractor-implement combination is in the field. The $D P$ includes the non-working time, turning time at the end of the passes, refill time, and any other non-productive time period of the implement. Ultimately the FE, width of the machine and the operational speed of the machine will yield the field capacities $(\mathrm{ha} / \mathrm{h})$ of the machines. TFR is the key parameter which will enable the determination of productive (WP) and non-productive (DP) times of the machine required for the calculation of $\mathrm{FE}$ and thus the following discussion pertains to the determination of the TFR

\section{DETERMINATION OF THE TFR}

The TFR is a function of draft power and the speed of operation. The speed of operation was obtained from the NMEA GPS data whereas, the draft power $(\mathrm{kW})$ required to pull the field cultivator and planter were predicted using the draft force equation 2 presented in the ASAE D497.7, a machinery management data standard (ASABE Standards, 2011).

$$
D=F_{i}\left[A+B(S)+C(S)^{2}\right] W T
$$

where

$D=$ implement $\operatorname{draft}(\mathrm{N})$

$F=$ a dimensionless soil texture adjustment parameter

$i=1$ for fine, 2 for medium, and 3 for coarse textured soils

$A, B$ and $C=$ machine specific parameters

$W=$ machine width, $\mathrm{m}$ or number of rows or tools 
$T=$ tillage depth, $\mathrm{cm}$ for major tools, 1 (dimensionless) for minor tillage tools and seeding implements

The tractor is said to be in a working condition if the load on the engine is greater than or equal to the draft power requirement calculated using equation 2 . The load on the engine will be higher than just the draft power requirement as there will be additional power required to overcome motion resistance of the tractor and implement and any PTO power required to power the implement. Thus, a tractor is considered to be in a working condition if the engine load is the minimum required for the draft load of the implement.

Equation 2 was used to calculate the draft force requirement of the field cultivator and the row crop planter. However, for the anhydrous applicator, equation 2 could not be used as the machine specific parameters $\mathrm{A}, \mathrm{B}$, and $\mathrm{C}$ were not available in machinery management data standard. Instead, soil tillage force prediction models developed by Godwin and O'Dogherty (2007) for narrow tines were used to determine the draft force requirement of the anhydrous applicator. A draft force of $1.26 \mathrm{kN} \mathrm{tool}^{-1}$ was calculated for the anhydrous applicator at an operating speed of $7.91 \mathrm{kmh}^{-1}$ based on their excel spreadsheet model (Godwin and O'Dogherty, 2007; and Upadhyaya et al., 2009).

Draft power requirement for each implement was obtained by multiplying the speed of operation and the draft force. This draft power was converted to equivalent Power Take Off (PTO) power using the tractive efficiency factors for 4WD and MFWD (ASABE Standards, 2011). The equivalent PTO power was used in equation 3 ( $A S A B E$ Standards, 2011) for determining the specific fuel consumption of the tractor used to pull the implement based on the load demand.

$$
S F C_{v}=\left(0.22+\frac{0.096}{X}\right) P T M
$$

where

$$
\begin{aligned}
& S F C_{v} \quad=\text { Specific Fuel Consumption }\left(\frac{L}{k W h}\right) \\
& \begin{aligned}
X \quad= & \text { fraction of equivalent PTO power }
\end{aligned} \\
& \begin{aligned}
& X=\left(\frac{P_{\text {load }}}{P_{\text {rated }}}\right) \\
& P_{\text {load }} \quad= \text { equivalent PTO power required by the current } \\
& \text { operation }(\mathrm{kW}) \\
& P_{\text {rated }} \quad= \text { rated PTO power available }(\mathrm{kW}) \\
& P T M=\text { partial throttle multiplier } \\
& P T M \quad= 1-(\mathrm{N}-1) .(0.45 . \mathrm{X}-0.877) \\
& N \quad=\text { ratio of partial throttle engine speed to full } \\
& \text { throttle engine speed }
\end{aligned}
\end{aligned}
$$

The 4WD tractor used to pull the field cultivator and anhydrous applicator, and the MFWD tractor used for planting were operated at full throttle, so PTM was assumed to be 1 in equation 3 . The equivalent PTO power calculated for the implement $\left(P_{\text {load }}\right)$, and the rated PTO power of the $4 \mathrm{WD}$ tractor $\left(P_{\text {rated }}\right)$ (refer to table 1 ) were used to determine $X$ which was used in equation 3 to determine the $S F C_{v}$. The $S F C_{v}$ was multiplied by the $P_{\text {load }}$ to obtain the engine fuel use rate in $\mathrm{Lh}^{-1}$. This fuel use rate was used as the TFR to distinguish between WP and DP of the field operations. This procedure was repeated for MFWD tractor to calculate the $P_{\text {load }}, S F C_{v}$, and the TFR. As an example, for the anhydrous applicator used in the study (refer to table 1), $P_{\text {load }}, S F C_{v}$, and TFR were calculated as $48.9 \mathrm{~kW}, 0.70 \mathrm{~L}(\mathrm{kWh})^{-1}$, and $34.3 \mathrm{Lh}^{-1}$, respectively, for a ground speed of $7.91 \mathrm{kmh}^{-1}$.

\section{DETERMINATION OF THE FE}

Spatial data obtained from the FMX monitor revealed that the average speed of operation was different for most of the field operations in headland passes when compared to the speed of operation in parallel passes. Speed of operation plays a significant role in predicting the draft force requirement of the implement (refer to eq. 2). Thus, the draft power requirement was different in headlands and parallel passes which yielded different TFR for the same operation. Higher speed resulted in higher draft loads and hence higher TFR. So, two TFR values were used, one for headland passes $\left(\mathrm{TFR}_{\mathrm{h}}\right)$ and the other for parallel passes $\left(\mathrm{TFR}_{\mathrm{p}}\right)$, to distinguish between WP and DP for each field operation.

$\mathrm{TFR}_{\mathrm{h}}$ and $\mathrm{TFR}_{\mathrm{p}}$ were determined based on the implement ground speeds in headland passes and parallel passes, respectively. The average ground speeds in headland and parallel passes were used in equation 2 to determine the draft force requirement which subsequently yielded $\mathrm{TFR}_{\mathrm{h}}$ and $\mathrm{TFR}_{\mathrm{p}}$. Based on these TFR values, two FE values were determined for each field, $\mathrm{FE}$ of headland passes $\left(\mathrm{FE}_{\mathrm{h}}\right)$, and $\mathrm{FE}$ of parallel passes $\left(\mathrm{FE}_{\mathrm{p}}\right)$. Using equation $1, \mathrm{FE}_{\mathrm{h}}$ and $\mathrm{FE}_{\mathrm{p}}$ were calculated where, WP and DP within headland passes $\left(\mathrm{WP}_{\mathrm{h}}\right.$ and $\left.\mathrm{DP}_{\mathrm{h}}\right)$ and, WP and DP within parallel passes $\left(\mathrm{WP}_{\mathrm{p}}\right.$ and $\left.\mathrm{DP}_{\mathrm{p}}\right)$ were used. The total $\mathrm{FE}\left(\mathrm{FE}_{\mathrm{tot}}\right)$ of each operation was calculated using equation 4 .

$$
\begin{aligned}
F E_{\text {tot }}(\text { decimal }) & =\frac{t_{h}}{t_{t}}\left(\frac{W P_{h}}{\left(W P_{h}+D P_{h}\right)}\right) \\
& +\frac{t_{p}}{t_{t}}\left(\frac{W P_{p}}{\left(W P_{p}+D P_{p}\right)}\right)
\end{aligned}
$$

where

$F E_{\text {tot }}=$ total field efficiency (decimal)

$t_{h}=$ time (s) spent by the tractor in headland passes

$t_{p} \quad=\quad$ time (s) spent by the tractor in parallel passes

$t_{t}=t_{h}+t_{p}=$ total time (s) spent by the tractor in the field

$\frac{t_{h}}{t_{t}}=$ fraction of total time (decimal) spent by the tractor

in headland passes

$\frac{t_{p}}{t_{t}}=$ fraction of total time (decimal) spent by the tractor

in parallel passes

$W P_{h}=$ working period in headland passes (s)

$D P_{h}=$ dwell period in headland passes (s)

$W P_{p}=$ working period in parallel passes (s)

$D P_{p}=$ dwell period in parallel passes (s) 


\section{RESULTS AND DISCUSSION}

\section{DEVELOPMENT AND EVALUATION OF TFR FOR $\mathrm{NH}_{3}$}

Application, Cultivation, and Planting

The decoded CAN fuel use rate data obtained from the tractor during anhydrous application in field $4 \mathrm{~A}$ is presented in figure 4 which illustrates that the fuel use rate variations are periodic. The fuel use rate reaches a maximum of $87 \mathrm{Lh}^{-1}$ and a low of $1 \mathrm{Lh}^{-1}$ but predominantly ranges between approximately 12 and $74 \mathrm{Lh}^{-1}$ when the tractor is moving in the field.

The fuel use rate profile of the anhydrous applicator for the first 1500 seconds (fig. 5) during the headland pass reveals the working periods, non-working periods, and the transition periods between working and non-working periods. High fuel use rates between 42 and $66 \mathrm{Lh}^{-1}$ are indicative of higher engine loads and correspond to the condition where the implement is engaged in the soil. Thus, these periods of high fuel use (fig. 5a) can be considered as
WPs of the implement. When the implement is disengaged from the soil, the draft force and corresponding fuel use rates both drop. The periods of low fuel use rate (fig. 5b) correspond to periods when the implement is out of the ground or DPs.

WPs correlate to the parallel passes when the implement is applying anhydrous, whereas DPs correspond to turning movements within the headlands at the end of the passes. When the tractor is near end of the pass, the implement is raised and the tractor transitions from a high draft power situation to low draft power situation (fig. 5c). After finishing the turn, the implement is re-engaged with the soil (see fig. 5d) in the next pass causing the fuel use rate to increase. The higher value stabilizes indicating full engagement of the implement. Thus, a series of WPs and DPs can be distinguished by observation from the fuel use rate profile.

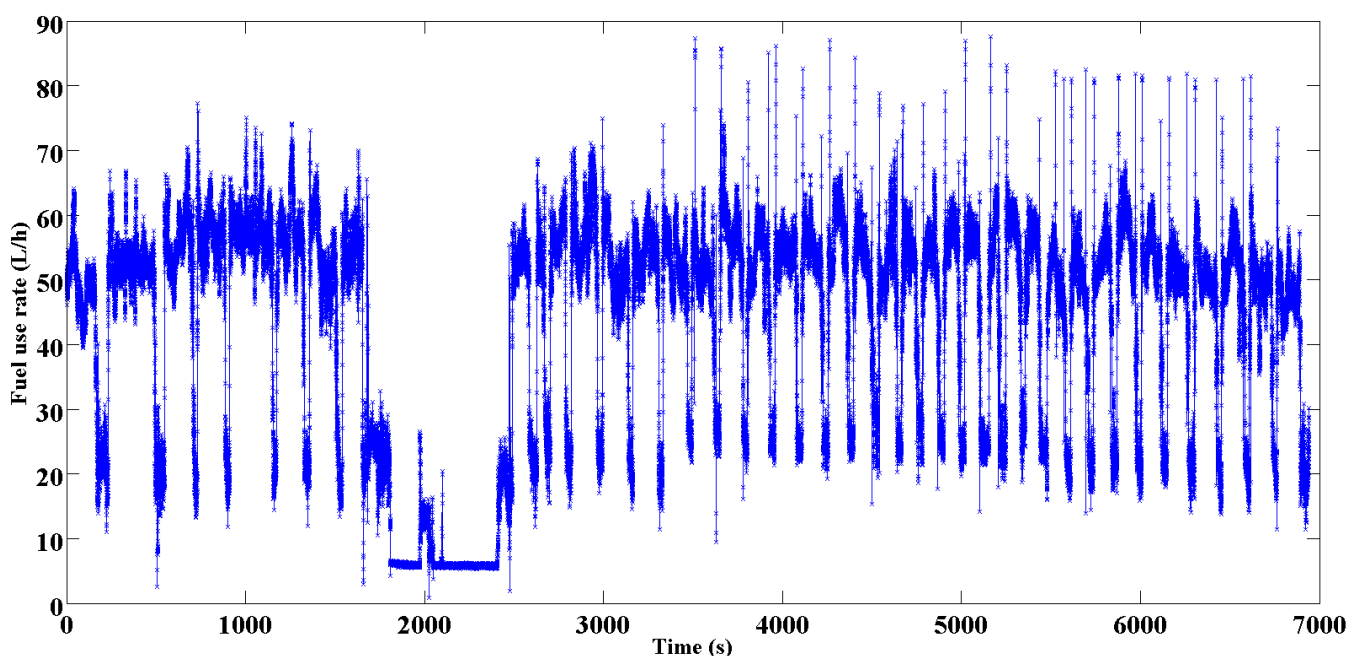

Figure 4. Fuel use rate profile of the 4WD tractor during anhydrous application in Field 4A.

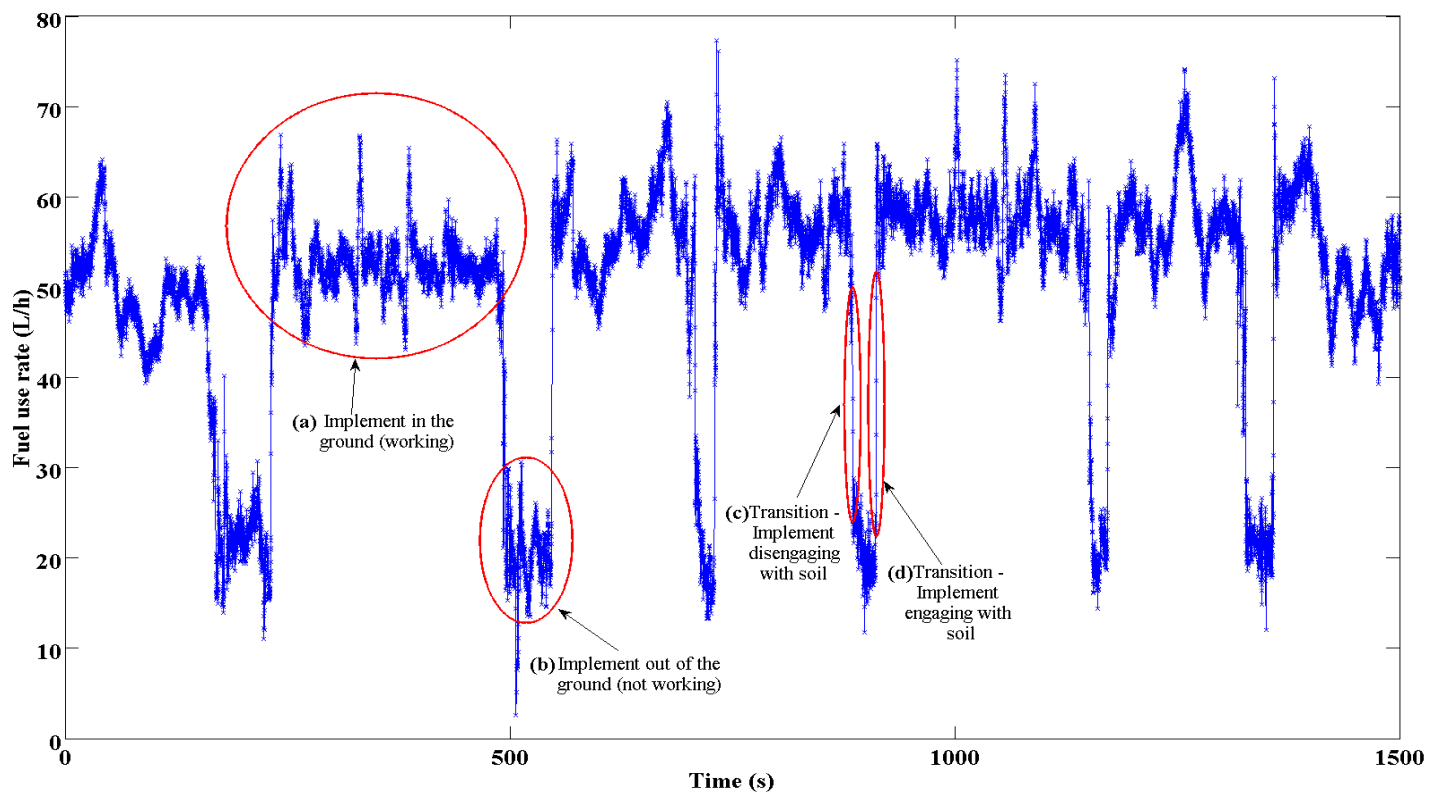

Figure 5. Fuel use rate profile for the first $1500 \mathrm{~s}$ of the anhydrous applicator in Field 4A. 


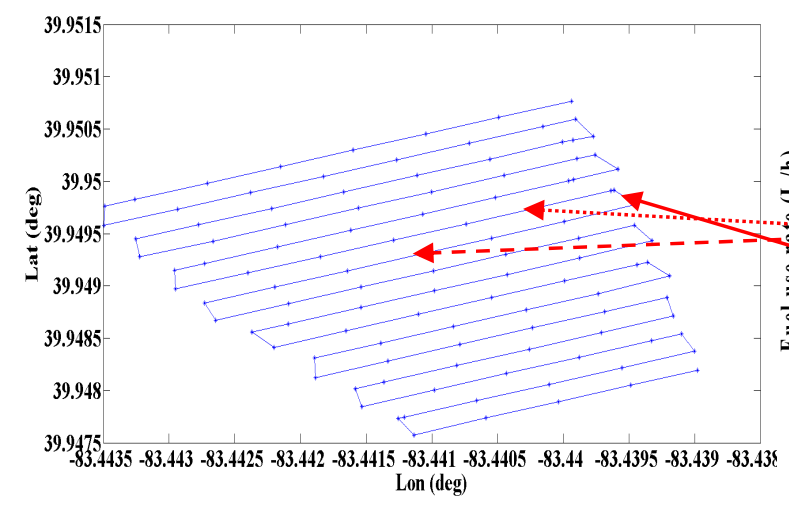

(a)

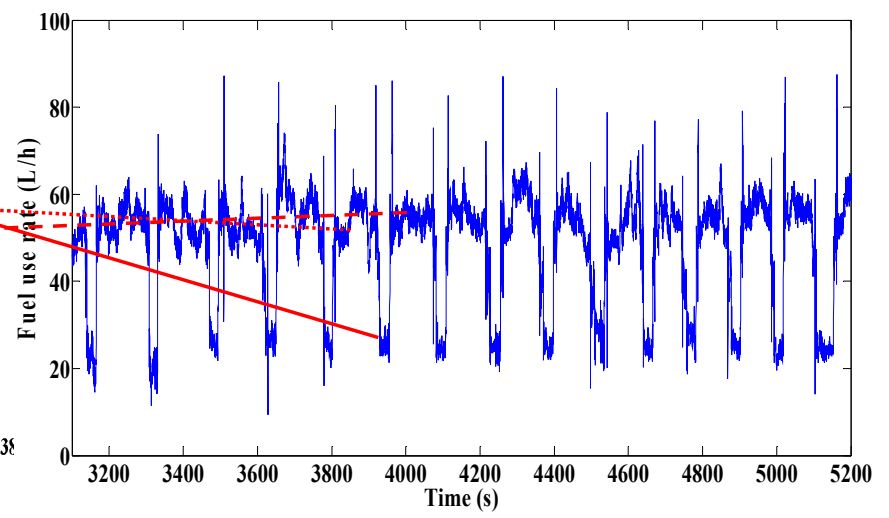

(b)

Figure 6. (a) Tractor path in parallel passes (b) WP and DP correlation with parallel passes and turning.

GPS data obtained from the FMX monitor were plotted (fig 6a) to observe the tractor path during anhydrous application. The WPs and DPs of the fuel use rate profile match the parallel passes and turning movements of the tractor (see fig. 6) which confirms the assumption of high fuel use rates corresponding to the working state condition and low fuel rates corresponding to non-working state of the implement. The GPS data from the FMX monitor and the CAN fuel use rate data were matched based on the time stamps.

Based on equation 3, the anhydrous applicator would require at least $34.3 \mathrm{Lh}^{-1}$ of fuel while operating at a speed of $7.91 \mathrm{kmh}^{-1}$ at tool depth of $22 \mathrm{~cm}(8.5 \mathrm{in}$.). Correspondingly, the fuel use rate data points greater than or equal to a $\mathrm{TFR}_{\mathrm{h}}$ of $34.3 \mathrm{Lh}^{-1}$ in the headland pass correspond to the $\mathrm{WP}_{\mathrm{h}}$ of the applicator, while data points below the $\mathrm{TFR}_{\mathrm{h}}$ correspond to the $\mathrm{DP}_{\mathrm{h}}$ (fig. 7). The average ground speed in the headland pass was $7.91 \mathrm{kmh}^{-1}$ whereas, for parallel passes it was $7.75 \mathrm{kmh}^{-1}$ and thus a TFR $\mathrm{h}$ of $34.3 \mathrm{Lh}^{-1}$ and $\mathrm{TFR}_{\mathrm{p}}$ of $34.1 \mathrm{Lh}^{-1}$ were used.

From figure 7, an extended DP between 1800 and $2400 \mathrm{~s}$ is observed indicating non-productive time which did not correspond to the turning time. From notes taken during the field operation, this likely occurred when the operator changed anhydrous tanks. For anhydrous application in Field 4A, the average speed of operation in the headland passes and the parallel passes were very close to each other (7.91 and $7.75 \mathrm{kmh}^{-1}$ ) however, that was not the case for some of the other operations. In Field 1C during cultivation (secondary tillage) operation, there was a significant difference between the speeds of operations in headland passes and parallel passes (fig. 8). Vehicle speed data obtained from the FMX Trimble monitors were plotted to observe the variation in vehicle speed. The average speed of operation for the headland operation was $6.86 \mathrm{kmh}^{-1}$ whereas, for the parallel passes it was $9.45 \mathrm{kmh}^{-1}$.

Also, from figure 8 , it can be observed that the speed variation was substantial during the headland pass compared to the parallel passes indicating the tractor might have slowed down and accelerated frequently in the headland passes. The effect of ground speed variation in the headland pass is reflected in the fuel use rate of the tractor (fig. 9). Compared to the fuel use rate during parallel passes fuel use during the headland pass is aperiodic.

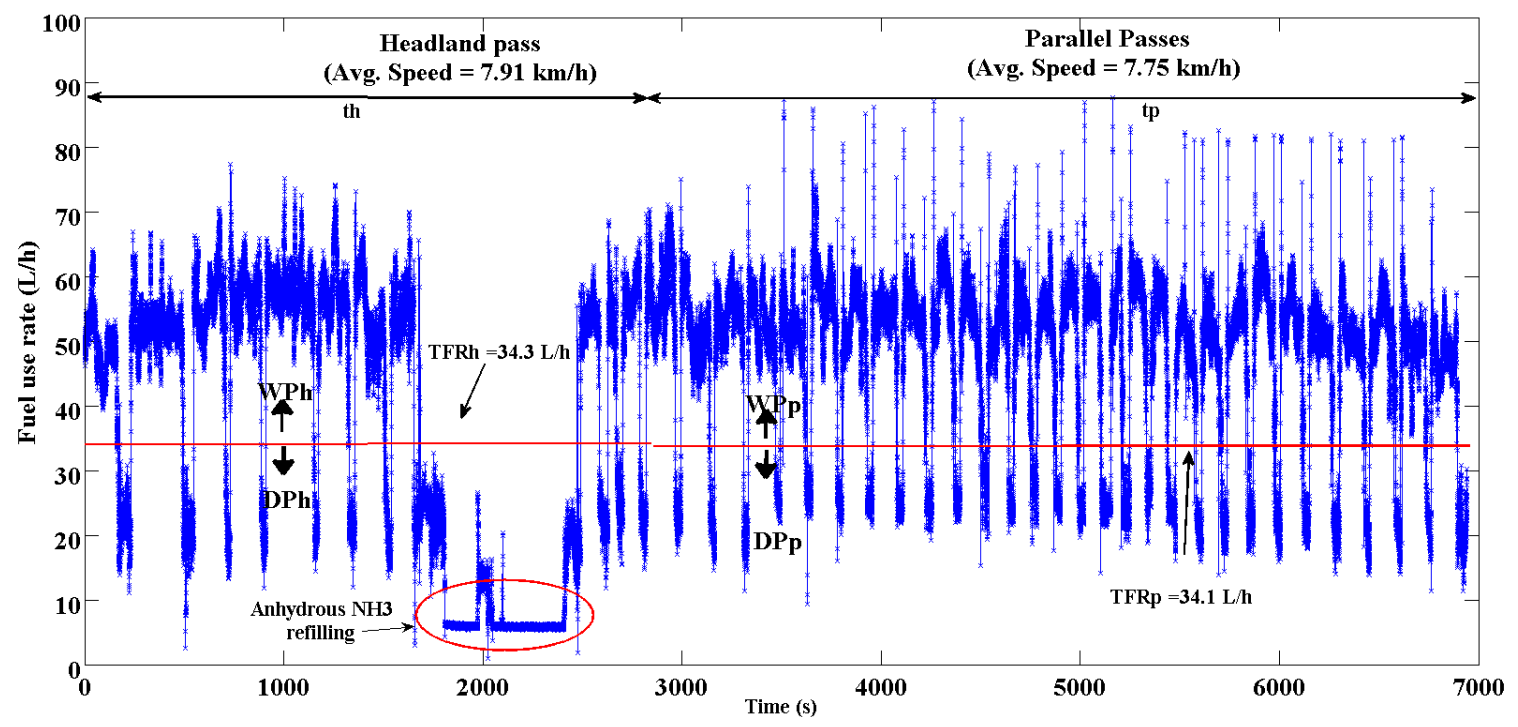

Figure 7. WP and DP of the anhydrous applicator separated by the TFR in Field 4A. 


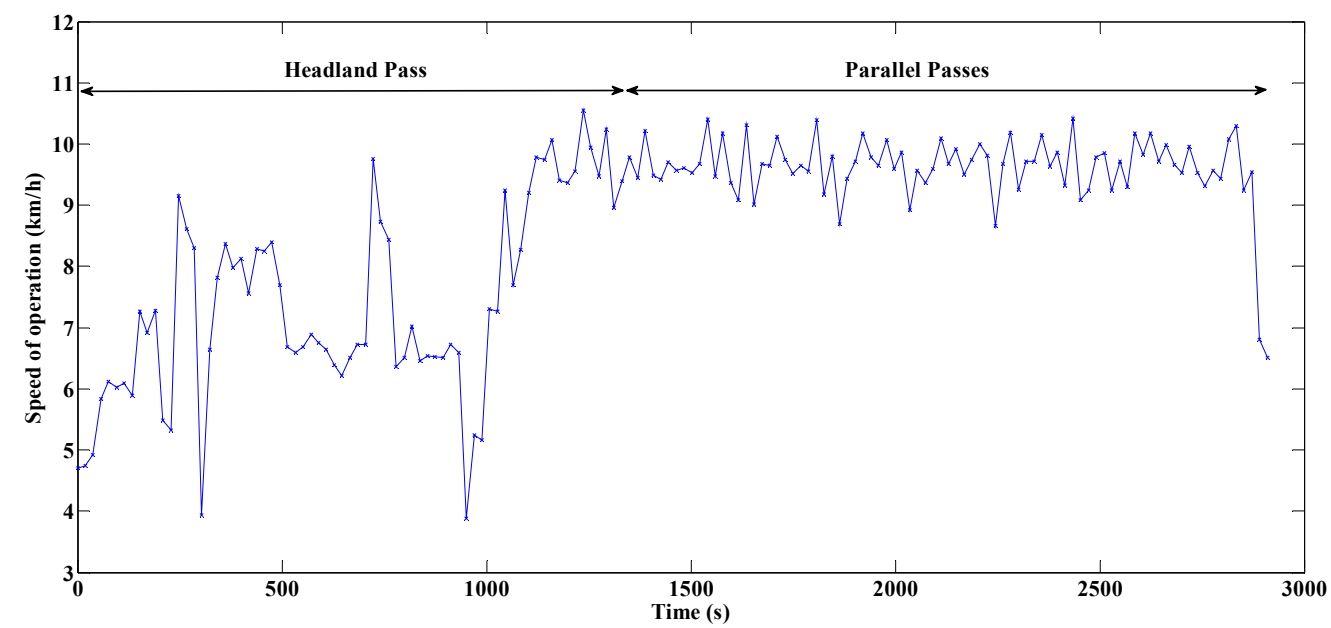

Figure 8. Tractor speed variation in headland pass vs. parallel passes in Field 1C during field cultivation.

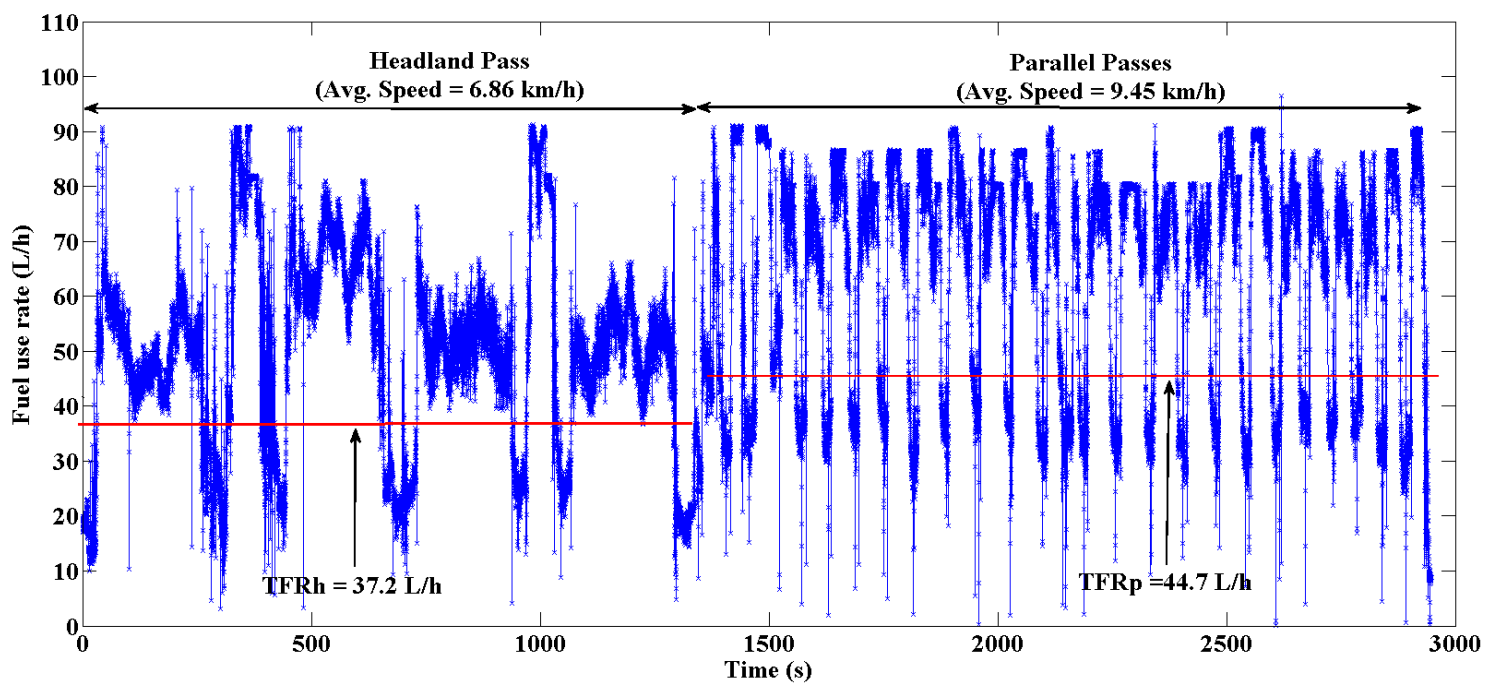

Figure 9. $\mathrm{TFR}_{\mathrm{h}}$ and $\mathrm{TFR}_{\mathrm{p}}$ of the field cultivator in Field $\mathbf{1 C}$.

Based on equation 3, for an average operational speed of $6.86 \mathrm{kmh}^{-1}$ in headland operation, a TFR $\mathrm{h}$ of $37.2 \mathrm{Lh}^{-1}$ was calculated. Similarly, for an average speed of $9.45 \mathrm{kmh}^{-1} \mathrm{a}$ $\mathrm{TFR}_{\mathrm{p}}$ of $44.7 \mathrm{Lh}^{-1}$ was calculated for the parallel passes (fig. 9).

Fuel use rate profile of the planting operation in Field $1 \mathrm{C}$ is presented in figure 10 . It can be observed that there were numerous non-productive times that did not correspond with turning times. As one might expect, the tractor operator stopped frequently to check seed spacing and depth as this was the first field that was planted during the season. Also, on multiple occasions, adjustments were made to parameters within the planter monitor to ensure ideal seed spacing and depth of planting.

Between times 5200 and 7000 s (fig. 10), the planter was relatively productive as you can see a series of WPs where the planter was performing parallel passes, and DPs that only corresponded to turning times.

A summary of the average speeds of operation of all the implements in the headland passes and parallel passes and their TFR values are presented in table 2 . The biggest difference in average ground speeds between headland and parallel passes occurred for field cultivation in field 1C with a difference of more than $2.5 \mathrm{kmh}^{-1}$ (table 2).

For rest of the operations with the exception of field cultivation in Field 2D, the difference in the average ground speeds were within $1 \mathrm{kmh}^{-1}$. The average ground speed was higher in parallel passes compared to headland passes for all the fields except for anhydrous application in Field 4A and planting in Field 2D (table 2).

\section{DETERMINATION AND EVALUATION OF FE FOR $\mathbf{N H}_{3}$ Application, Cultivation, and Planting}

Based on the $\mathrm{TFR}_{\mathrm{h}}$ and $\mathrm{TFR}_{\mathrm{p}}$ values presented in table 2, FE values of $\mathrm{NH}_{3}$ application, cultivation, and planting were determined. $\mathrm{WP}_{\mathrm{h}}, \mathrm{DP}_{\mathrm{h}}, \mathrm{WP}_{\mathrm{p}}$, and $\mathrm{DP}_{\mathrm{p}}$ in headland and parallel passes (fig. 7) were determined using $\mathrm{TFR}_{h}$ and $\mathrm{TFR}_{\mathrm{p}}$. $\mathrm{WP}_{\mathrm{h}}$, $\mathrm{DP}_{\mathrm{h}}, \mathrm{WP}_{\mathrm{p}}$, and $\mathrm{DP}_{\mathrm{p}}$ were used in equation 1 to calculate $\mathrm{FE}_{\mathrm{h}}$

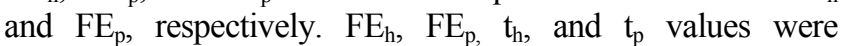
substituted in equation 4 to determine $\mathrm{FE}_{\text {tot }}$ of the anhydrous application, cultivation, and planting operation. 


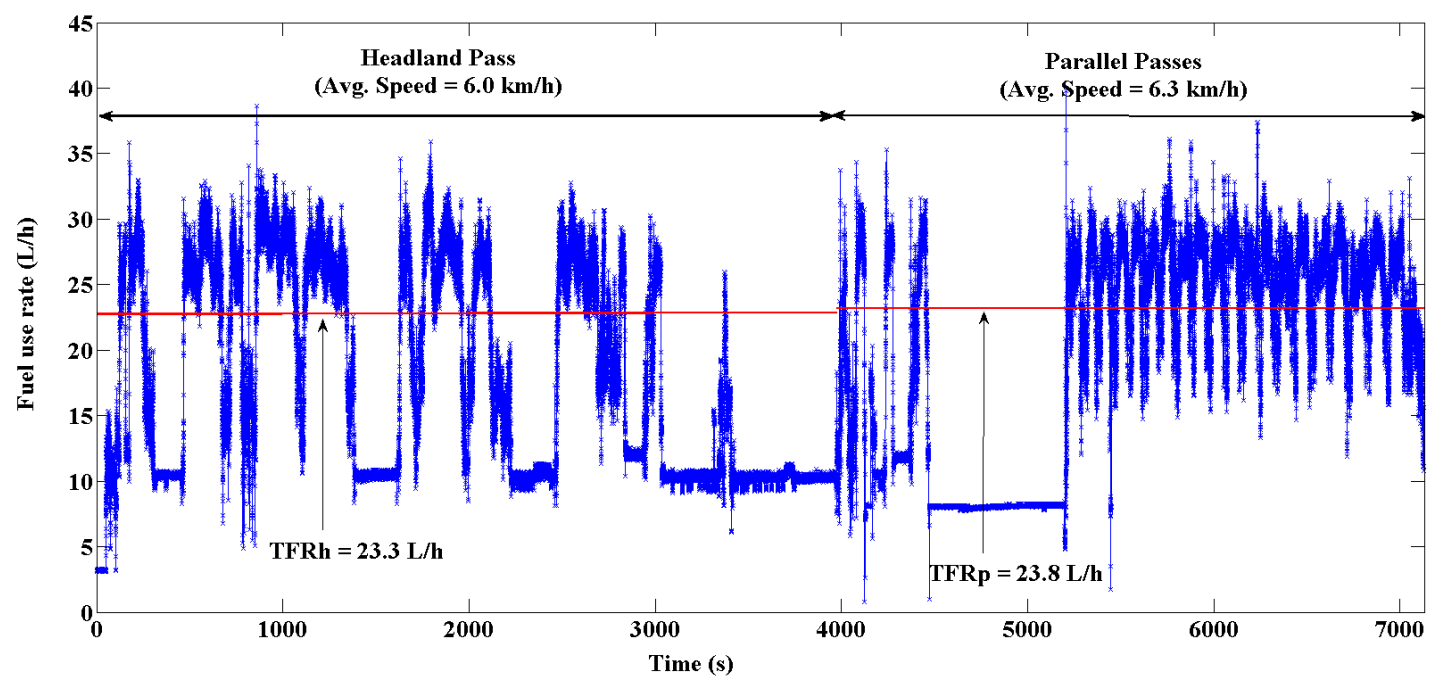

Figure 10. TFR $\mathrm{h}_{\mathrm{h}}$ and $\mathrm{TFR}_{\mathrm{p}}$ of the corn planter in Field $\mathbf{1 C}$.

Table 2. Summary of average speeds of operation and TFR in headland and parallel passes.

\begin{tabular}{llcccc}
\multicolumn{7}{c}{ and TFR in headland and parallel passes. } \\
\hline & $\begin{array}{c}\text { Avg Speed } \\
\left(\mathrm{kmh}^{-1}\right)-\end{array}$ & $\begin{array}{c}\text { Avg Speed } \\
\left(\mathrm{kmh}^{-1}\right)-\end{array}$ & $\begin{array}{c}\mathrm{TFR}_{\mathrm{h}} \\
\text { Headland Pass }\end{array}$ & $\begin{array}{c}\mathrm{TFR}_{\mathrm{p}} \\
\left(\mathrm{Parallel} \mathrm{Passes}^{-1}\right)\end{array}$ \\
\hline \multirow{2}{*}{$\begin{array}{l}\text { Anhydrous } \\
\text { application }\end{array}$} & Field 4A & 7.91 & 7.75 & 34.3 & 34.1 \\
& Field & & & & \\
& 3MSID & 7.48 & 7.43 & 33.7 & 33.6 \\
\hline \multirow{2}{*}{ Field } & Field 1C & 6.86 & 9.45 & 37.2 & 44.7 \\
cultivation & Field 2C & 8.64 & 9.32 & 42.3 & 44.3 \\
& Field 2D & 8.36 & 9.46 & 41.5 & 44.7 \\
\hline \multirow{2}{*}{ Corn } & Field 1C & 6 & 6.3 & 23.3 & 23.8 \\
planting & Field 12D & 7.65 & 7.9 & 25.4 & 25.0 \\
& Field 2D & 7.32 & 7.06 & 26 & 26.4 \\
\hline
\end{tabular}

Table 3 provides the summary of $\left(\mathrm{FE}_{\mathrm{tot}}\right)$ for all fields and implements and the percent of total time spent by the implements in headland versus parallel passes.

For most cases, $\mathrm{FE}_{\mathrm{h}}$ values were lower than $\mathrm{FE}_{\mathrm{p}}$ values indicating that the tractor's working time was higher than the non-working time in parallel passes compared to the headland passes. This is intuitive as the tractor incurs more non-productive time in the headland pass where the implement adjustments and maneuvering at irregular field borders takes place. In parallel passes however, the only non-productive time is typically turning at the ends. For field cultivation operation in Field $2 \mathrm{C}, \mathrm{FE}_{\mathrm{h}}$ was significantly higher than $\mathrm{FE}_{\mathrm{p}}$. Upon further investigation the only aspect of this operation that differentiated itself from the other operations is that headland coverage occurred towards the end of field cultivation which was not typical for the other field operations. The machine path from GPS data indicated that the field was cultivated in parallel passes prior to headland cultivation. So, non-productive times which happen at the beginning of the operation (e.g., implement set up time, auto guidance setup time, etc.) might have occurred in parallel passes instead of headland passes. However, the overall $\mathrm{FE}_{\text {tot }}$ of Field $2 \mathrm{C}$ remains close to the $\mathrm{FE}_{\text {tot }}$ values of field cultivation in other fields (table 3.) despite high $\mathrm{FE}_{\mathrm{h}}$ value.

Average $\mathrm{FE}$ values of the implements calculated using the TFRs were compared to the FE values of the planter and the field cultivator (table 4) suggested in the standard document ASAE 497.7 (ASABE Standards, 2011).

From literature, it was reported that implements with larger widths have lower FEs compared to smaller widths (Taylor et al., 2001). For implements with the same widths, field efficiencies in irregular-shaped fields were lower compared to working in rectangular fields as the turning times and non-productive movements will be greater in fields with more contour passes as opposed to fields with straight passes (Grisso et al., 2002). Thus, it is highly unlikely to match the FE values obtained from the TFR methodology with the FE values suggested in the ASABE standards and other studies (see table 4) unless the implements and the fields in which they worked are the same. However, the values calculated by the TFR methodology fall within the ranges provided by ASABE machinery management standard (ASABE Standards, 2011), and are close to other research studies (Grisso et al., 2002 and Taylor et al., 2001).

Table 3. FE values for anhydrous $\mathrm{NH}_{3}$ application, field cultivation and corn planting.

\begin{tabular}{|c|c|c|c|c|c|c|}
\hline & & $\begin{array}{c}\mathrm{FE}_{\mathrm{h}} \\
\text { (decimal) }\end{array}$ & $\begin{array}{c}\mathrm{t}_{\mathrm{h}} / \mathrm{t}_{\mathrm{t}} \\
\text { (decimal) }\end{array}$ & $\begin{array}{c}\mathrm{FE}_{\mathrm{p}} \\
\text { (decimal) }\end{array}$ & $\begin{array}{c}\mathrm{t}_{\mathrm{p}} / \mathrm{t}_{\mathrm{t}} \\
\text { (decimal) }\end{array}$ & $\begin{array}{c}\mathrm{FE}_{\text {tot }} \\
\text { (decimal) }\end{array}$ \\
\hline \multirow[t]{2}{*}{ Anhydrous application } & Field 4A & 0.6 & 0.44 & 0.79 & 0.56 & 0.71 \\
\hline & Field 3MSID & 0.64 & 0.43 & 0.74 & 0.57 & 0.70 \\
\hline \multirow[t]{3}{*}{ Field cultivation } & Field 1C & 0.68 & 0.53 & 0.72 & 0.47 & 0.70 \\
\hline & Field 2C & 0.82 & 0.22 & 0.69 & 0.78 & 0.72 \\
\hline & Field 2D & 0.72 & 0.6 & 0.71 & 0.4 & 0.71 \\
\hline \multirow[t]{3}{*}{ Corn planting } & Field 1C & 0.38 & 0.54 & 0.46 & 0.46 & 0.42 \\
\hline & Field 2D & 0.7 & 0.39 & 0.7 & 0.61 & 0.70 \\
\hline & Field 12D & 0.65 & 0.27 & 0.66 & 0.73 & 0.66 \\
\hline
\end{tabular}


Table 4. FE comparison with ASABE standard and other research studies.

\begin{tabular}{|c|c|c|c|c|c|c|}
\hline & $\begin{array}{c}\text { FE - TFR } \\
\text { Methodology }\end{array}$ & $\begin{array}{c}\mathrm{FE}-\mathrm{ASABE} \\
(\mathrm{Min})\end{array}$ & $\begin{array}{c}\mathrm{FE}-\mathrm{ASABE} \\
\text { (Typical) }\end{array}$ & $\begin{array}{c}\mathrm{FE}-\mathrm{ASABE} \\
(\mathrm{Max})\end{array}$ & $\begin{array}{c}\mathrm{FE}-\text { Grisso et al } \\
2002 \\
\end{array}$ & $\begin{array}{c}\mathrm{FE}-\text { Taylor et al } \\
2001\end{array}$ \\
\hline Anhydrous application & 0.71 & $\mathrm{~N} / \mathrm{A}$ & N/A & $\mathrm{N} / \mathrm{A}$ & N/A & N/A \\
\hline Field cultivator & 0.71 & 0.70 & 0.85 & 0.90 & N/A & N/A \\
\hline Row crop planter & 0.68 & 0.50 & 0.65 & 0.70 & 0.66 & 0.62 \\
\hline
\end{tabular}

The TFR used to determine the FE was calculated based on the draft force requirement of the implement and the speed of operation. Keeping the operational speed constant, the draft power was varied $\pm 25 \%$ to account for a range of draft force requirements equation 3 (ASABE Standards, 2011). Thus, two more TFRs corresponding to $P_{\text {load }}-0.25$ $P_{\text {load }}$ and $P_{\text {load }}+0.25 P_{\text {load }}$ were calculated for each operation in addition to the TFR corresponding the $P_{\text {load }}$ (see eq. 3) for each implement. As an example, for anhydrous application in field $4 \mathrm{~A}$, in parallel passes, 31.4 $\mathrm{Lh}^{-1}, 34.1 \mathrm{Lh}^{-1}$ and $36.1 \mathrm{Lh}^{-1}$ TFRs corresponded to $P_{\text {load }}-0.25 P_{\text {load, }} P_{\text {load }}$ and $P_{\text {load }}+0.25 P_{\text {load, }}$, respectively. Similarly, three more TFRs were calculated for headland pass operation. Based on these TFRs, $\mathrm{FE}_{\mathrm{h}}, \mathrm{FE}_{\mathrm{p}}$, and $\mathrm{FE}_{\text {tot }}$ for each operation were determined and $\mathrm{FE}_{\text {tot }}$ were recalculated and plotted to observe the sensitivity to draft load (fig. 11).

$\mathrm{FE}_{\text {tot }}$ of anhydrous application was least affected by changes in the draft loads. The $\mathrm{FE}_{\text {tot }}$ remained at 0.71 in Field 4A even when the draft load varied between $P_{\text {load }}$ $0.25 P_{\text {load }}$ and $P_{\text {load }}+0.25 P_{\text {load }}$ indicating that we can predict the FEs of the anhydrous applicator as long as the predicted draft load is within $\pm 25 \%$ of the actual load on the tractor engine. Planting was the most affected as the $\mathrm{FE}_{\text {tot }}$ values varied significantly. This high sensitivity could be explained by comparing the fuel use rate profile of planting to the fuel use rate profiles of the anhydrous application and field cultivation (fig. 12). The difference between WP and DP fuel use for planting is less (approximately $15 \mathrm{Lh}^{-1}$ ) compared to the difference between the WP and DP fuel use for anhydrous application (approximately $40 \mathrm{Lh}^{-1}$ ) and field cultivation (approximately $\left.45 \mathrm{Lh}^{-1}\right)$. In the case of planting, in addition to the draft power, the central fill planter required power to drive hydraulic fan motors for conveying seed through the planter, requiring a PTO-driven hydraulic power supply. This additional power requirement might have caused the DP fuel use to be close to WP fuel use causing high density of fuel use rate data points in the transitions for the planting (fig. 12c). Fuel use rate transitions of anhydrous application, field cultivation and planting are compared in figure 12. Moving the TFR line up and down by even small increments in figure 12c means excluding or including a significant number of fuel use rate data points which affects the values of WPs and DPs.

$\mathrm{FE}_{\text {tot }}$ values of the planter ranged from 0.84 to 0.42 when the draft load $\left(P_{\text {load }}\right)$ was varied between $P_{\text {load }}$ $0.25 P_{\text {load }}$ and $P_{\text {load }}+0.25 P_{\text {load }}$ thus indicating that for planting operation, the draft load used in equation 3 needs to be as close as possible to the actual engine load. Using a wide range of draft loads, $\pm 25 \% P_{\text {load }}$, for planting (demonstrated here) could yield inaccurate FE values. Since FE values for the planting operation were highly sensitive to wider range draft load variation $\left( \pm 25 \% P_{\text {load }}\right)$, a smaller range was selected. Sensitivity of FE values to a load range of $\pm 5 \%\left(P_{\text {load }}-0.05 P_{\text {load }}\right.$ to $\left.P_{\text {load }}+0.05 P_{\text {load }}\right)$, were plotted in figure 13. Using a smaller range of draft loads yielded reasonable range of FE values for the planter in all the fields. This sensitivity analysis indicated that for the planting operation, the TFR methodology can be applied as long as the draft loads used in equation 3 are within a close tolerance range of the actual load.

TFR values used to determine FEs of all operations from table 2 are divided by the number of tools or rows to obtain TFR per tool/row of the implements. In the case of field cultivator and anhydrous applicator the TFR values were divided by number of tools, 13 for anhydrous applicator, and 90 for field cultivator whereas, for the planter the TFR value was divided by 16 rows. The TFR per tool/row is plotted against operational speed in figure 14 .

For the anhydrous applicator, a TFR per tool of 2.58 to $2.64 \mathrm{Lh}^{-1}$ tool $^{-1}$ at an operational speed between 7.43 and $7.91 \mathrm{kmh}^{-1}$, and an operational depth of $22 \mathrm{~cm}$ (8.5 in.) can be used for determining the FE of the operation. Similarly for field cultivation, the TFR per tool ranges from 0.41 to $0.50 \mathrm{Lh}^{-1}$ tool $^{-1}$ for speeds between 7.43 and $9.46 \mathrm{kmh}^{-1}$ at an operating depth of $7 \mathrm{~cm}$ (2.8 in.). It can be observed that the TFR per tool for field cultivator is lower than that of

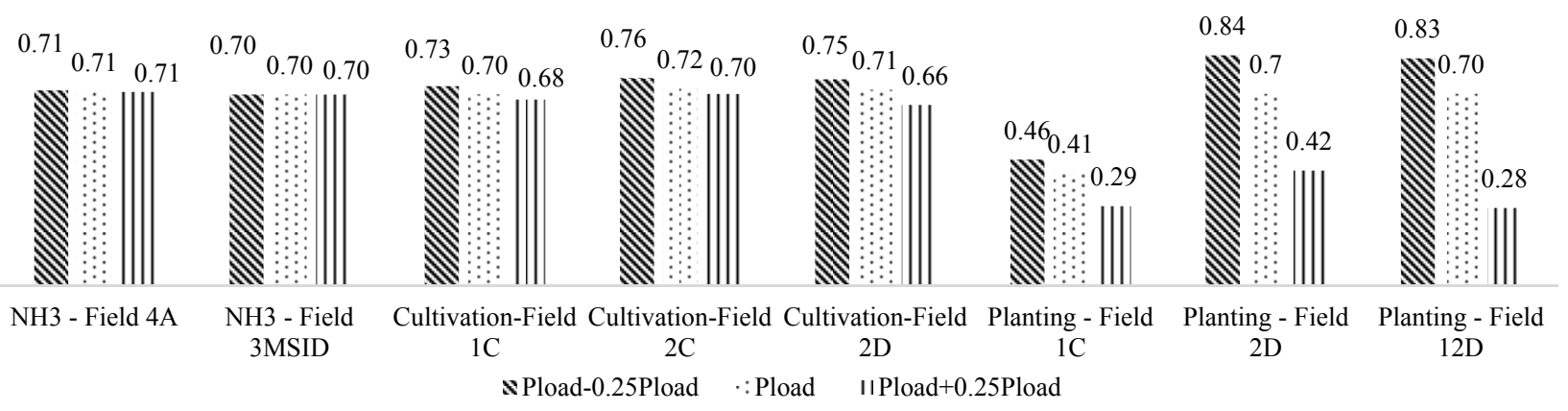

Figure 11. Sensitivity of $\mathrm{FE}_{\text {tot }}$ to draft load $\left(\mathrm{P}_{\text {load }}\right)$ variation $( \pm 25 \%)$. 

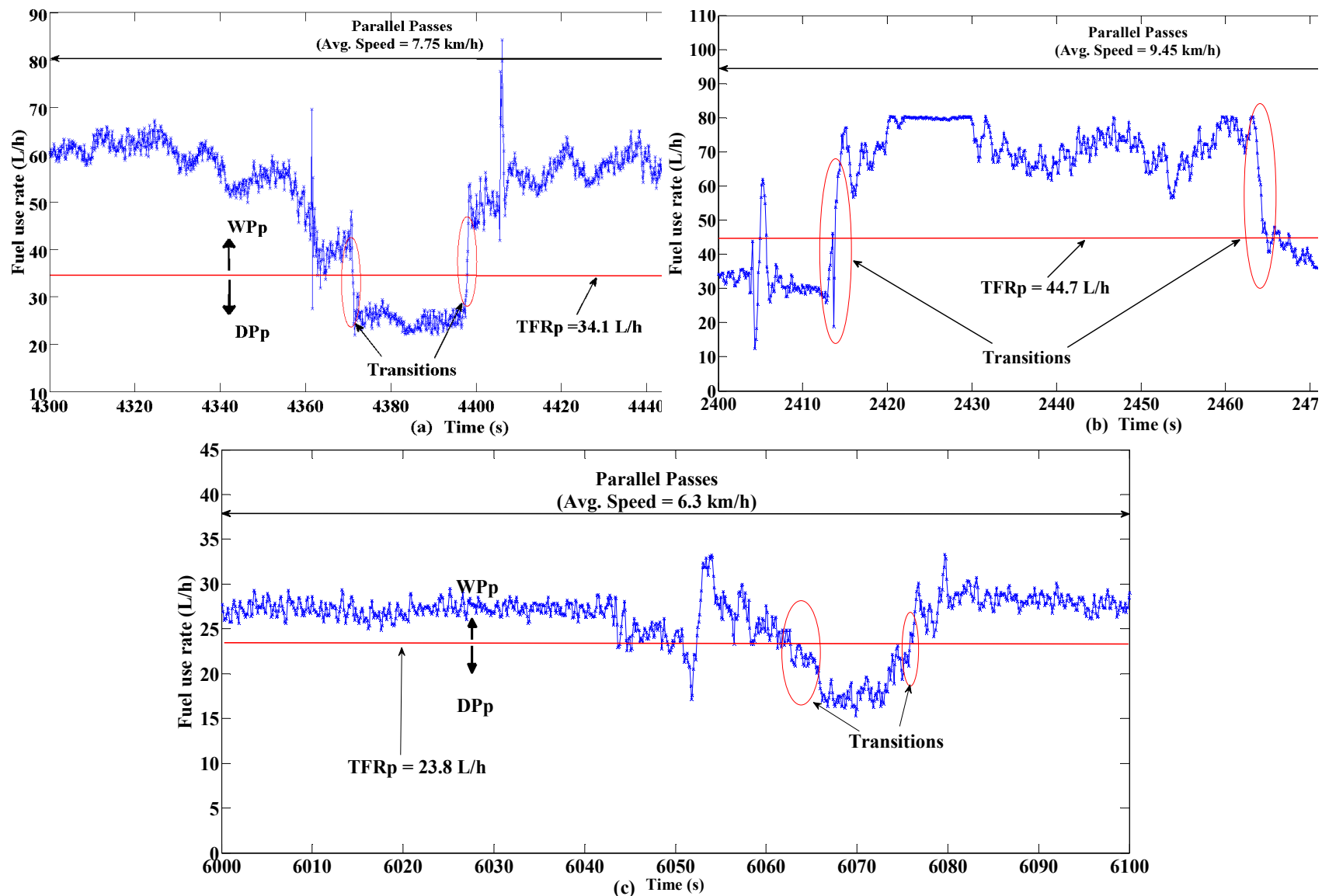

Figure 12. Comparison of the WP and DP fuel use rates, (a) anhydrous application in field $4 \mathrm{~A}$ and (b) field cultivation in Field 1C with (c) planting in Field 1C.

anhydrous application and planting. This could be explained by the fact the field cultivator was being used for secondary tillage and operating at a shallower depth of $7 \mathrm{~cm}$ (2.8 in.). Finally, for the central fill planter, the TFR per row ranges from 1.46 to $1.65 \mathrm{Lh}^{-1}$ row $^{-1}$ for operating speeds between 6.0 and $7.9 \mathrm{kmh}^{-1}$.

\section{CONCLUSIONS}

The ability to obtain CAN data from modern day agricultural equipment makes it possible not only to diagnose machine problems but also to monitor the field performance of the machines. In this study, CAN data were successfully recorded from equipment during field operations, decoded and analyzed. Analysis of the fuel use rate CAN data revealed the potential to predict the FEs of the machines based on tractor fuel consumption. TFRs for anhydrous applicator (2.58 to $2.64 \mathrm{Lh}^{-1}$ tool $\left.^{-1}\right)$, field cultivator $\left(0.41\right.$ to $0.50 \mathrm{Lh}^{-1}$ tool $\left.^{-1}\right)$, and a central fill corn planter (1.46 to $1.65 \mathrm{Lh}^{-1} \mathrm{row}^{-1}$ ) were established which yielded FEs of $71 \%, 71 \%$, and $68 \%$, respectively. Speed of operation and the draft load were the two major factors that affected TFR. Corn planting FE was more sensitive to variation in the draft load and TFR when contrasted with the anhydrous application and field cultivation. Hence, for equipment that uses PTO power in addition to the draft power (planter in this study), the predicted draft power has to be within a close tolerance, $\pm 5 \%$ in this case, of the

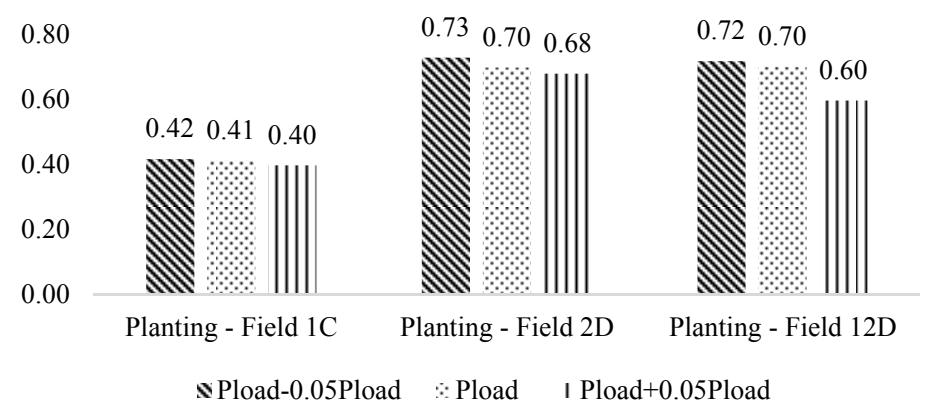

Figure 13. Sensitivity of $\mathrm{FE}_{\text {tot }}$ to draft load $\left(\mathrm{P}_{\text {load }}\right)$ variation $( \pm \mathbf{5 \%})$. 


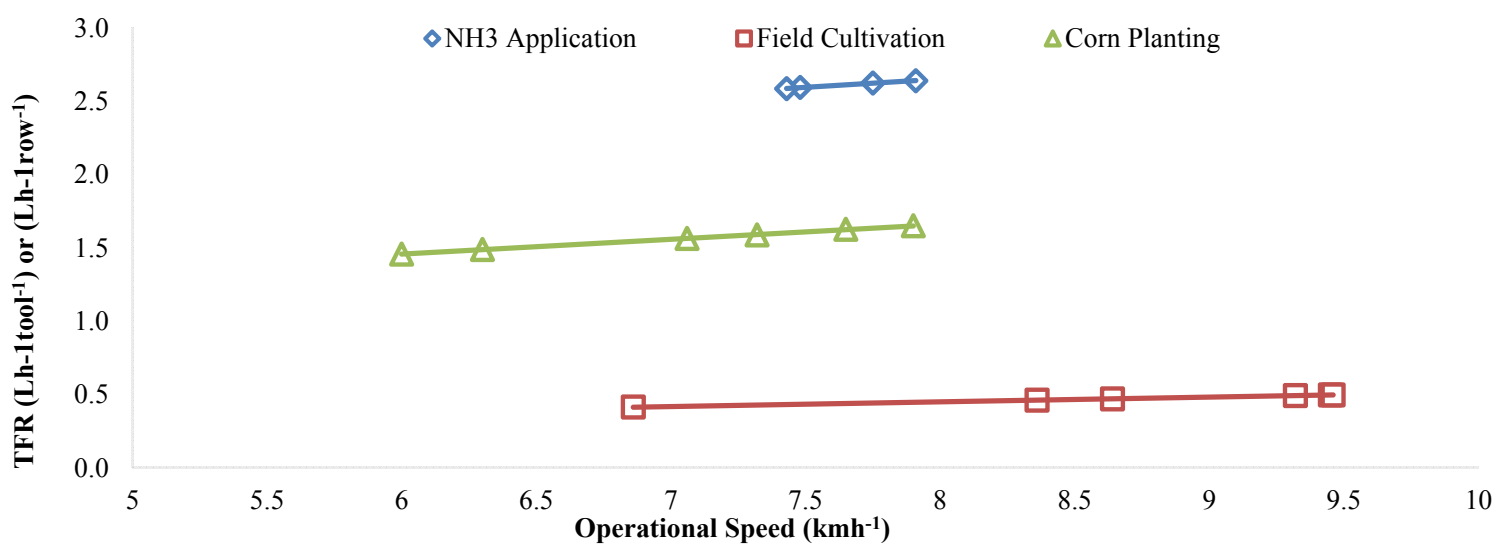

Figure 14. TFR per row/tool of anhydrous applicator, field cultivator, and corn planter.

actual engine load to obtain reasonable FE values. Thus based on the TFRs, a method to determine FEs of anhydrous application, field cultivation and planting was presented in this article. By monitoring just the fuel use rate of the tractor it was possible to determine the FEs of different field operations. Unlike other methods of determining FEs which require either spatial data or working states of implement valves/switches, this method requires only fuel use rate data. This method enables the already existing instrumentation on the tractor's engine to be used for FE prediction without the need of additional hardware or instrumentation on the implement.

\section{ACKNOWLEDGEMENTS}

The authors would like to thank Nathan Douridas, Chuck Gamble, and Matt Sullivan at the Farm Science Review, The Ohio State University, for their patience and support during the collection of the CAN data from the equipment. Also, the help from students, Andrew Klopfenstein, Dustin Wolters, Brittany Schroeder, and Karl Klopfenstein at the Department of Food, Agricultural and Biological Engineering at The Ohio State University is appreciated.

\section{REFERENCES}

ASAE Standards . (1999). S495: Uniform terminology for agricultural machinery manangement. St. Joseph, Mich.: ASAE. ASABE Standards. (2006). EP 496.3: Agricultural machinery management. St. Joseph, Mich.: ASABE.

ASABE Standards. (2011). D 497.7: Agricultural machinery management. St. Joseph, Mich.: ASABE.
Auernhammer, H., Demmel, M., \& Spangler, A. (2000). Automatic process data aquisition with GPS and LBS. EurAgEng Paper No. 00-IT005. AgEngWarwick.

Demmel, M., Ehrl, M., Rothmund, M., Spangler, A., \& Auernhammer, H. (2002). Automated process data acquisition with GPS and standardized communication-The basis for agricultural production traceability. ASAE Paper No. 023013. St. Joseph, Mich.: ASAE.

Godwin, R. J., \& O'Dogherty, M. J. (2007). Integrated soil tillage force prediction models. J. Terramech., 44(1), 3-14. http://dx.doi.org/10.1016/j.jterra.2006.01.001.

Grisso, R. D., Jasa, P. J., \& Rolofson, D. (2002). Analysis of traffic patterns and yield monitor data for field efficiency determination. Appl. Eng. Agric., 18(2), 171-178. http://dx.doi.org/10.13031/2013.7782.

Grisso, R. D., Kocher, M. F., Adamchuk, V. I., Jasa, P. J., \& Schroeder, M. A. (2004). Field efficiency determination using traffic pattern indices. Appl. Eng. Agric., 20(5), 563-572. http://dx.doi.org/10.13031/2013.17456.

SAE Standards. (2013). J1939: Serial control and communications heavy duty vehicle network - Top level document. Retrieved from http://standards.sae.org/j1939 201308/.

Stone, L. M., McKee, K. D., Formwalt, C. W., \& Benneweis, R. K. (1999). ISO 11783: An electronic communications protocol for agricultural equipment. ASAE Paper No.913C1798. St. Joseph, Mich.: ASAE.

Taylor, R. K., Schrock, M. D., \& Staggenborg, S. A. (2001). Using GPS technology to assist machinery management decisions. ASAE Paper No. MC01-24. St. Joseph, Mich. : ASAE.

Taylor, R. K., Schrock, M. D., \& Staggenborg, S. A. (2002). Extracting machinery management information from GPS data. ASAE Paper No. 02-10008. St. Joseph, Mich. : ASAE.

Upadhyaya, S. K., Chancellor, W. J., Perumpral, J. V., Wulfsohn, D., \& Way, T. R. (2009). Advances in Soil Dynamics. St. Joseph, Mich.: ASABE. 